\title{
Measuring Innovation in Mountain Destinations
}

\author{
Zuzana Lencsésová / e-mail: zuzana.lencsesova@umb.sk \\ Department of Tourism and Hospitality, Faculty of Economics, \\ Matej Bel University, Banská Bystrica, Slovakia
}

Lenscésová, Z. (2015). Measuring Innovation in Mountain Destinations. Czech Journal of Tourism, 4(1), 45-57. DOI: 10.1515/cjot-2015-0003.

\begin{abstract}
Innovation is an important tool for increasing the competitiveness of businesses or tourism destinations. In the mountain destinations the innovation has to be implemented in accordance to the principles of sustainable development. It is therefore necessary to measure the innovation rate and to explain the influence of various innovations groups on the development of mountain destinations.

The aim of the paper is to explore the structure of innovations in the Slovak and Swiss mountain destinations and to find out their innovation rate. In the context of measuring the innovations, two fundamental approaches are explained. The innovations implemented in 34 Slovak and 29 Swiss mountain destinations in 2013 are analysed on the basis of the information published in annual reports, which were complemented by the interviews with the managers of mountain destinations. The identified innovations are classified into innovations groups and ranked. The innovation rate in the defined innovations groups and the comprehensive innovation rate for all mountain destinations are detected. The article also explains the connection between the innovation rate and the destination life cycle phase.
\end{abstract}

\section{Keywords}

Innovation rate, mountain destinations, Slovakia, Switzerland

JEL classification: L83, O32/ Accepted: 10 December 2015 


\section{Introduction}

Innovation is a change, attributable to new products or services of higher quality, the introduction of new production processes and changes in the management and organization of work focused on bringing an added value and satisfying customer'needs. Nowadays, the innovation is mainly considered as a tool for increasing the competitiveness.

Tourism developed in the mountain destinations because their inhabitants did not mostly have any other option to earn money and survive. In the majority of mountain destinations, tourism is the main economic activity. The development of tourism, as well as the implementation of innovations in the mountain destinations have to raise living standards of inhabitants, protect the environment and also generate incomes for stakeholders. They should fulfil the social, ecological and economic principles of sustainable development in the mountain destinations.

In the mountain destinations the innovations have to increase the competitiveness with the respect to the principles of sustainable development because of the fragile nature, in which they are developed. The innovations in the mountain destinations are understood as a novelty, which has not been performed in that geographic area yet. For better management of the innovation in the mountain destinations, they have to be monitored and measured. It is necessary to determine the innovation rate and to explain the influence of various types of innovations on the mountain destination development.

\section{Theoretical basis}

The definition of the mountain resort and its characteristics is mainly in the geographic typologies of tourism destinations. The mountain destination, as a tourism destination, is mentioned in the papers of Slovak authors (Kuklica et al., 1965; Mariot 1983, 2001; Horák et al., 1985; Kopšo et al., 1989, 1992; Patúš, 2004; Gúčik, 2011; Gúčik \& Pěč, 2011, Gajdošík, 2014; Šebová, 2014) and foreign authors (Flagestad \& Hope, 2001; Medlik, 2003; Weiermair, 2006; Nepal \& Chipeniu, 2005; Matto \& Scott, 2008; Bourdeau, 2009; Keller, 2012; Kuščer, 2013).

The Slovak authors pay attention mainly to geographic and climatic requirements. Some of them (Kopšo, 1992; Patúš, 2004) focus mainly on the secondary supply, as a basis for tourism development. The common feature of the foreign authors' definitions of mountain destinations is in the identification of the activities that are carried out in the destination and not the geographic conditions. The mountain destination is mostly explained only in a descriptive way, without any clear definition of its essence and character.

In terms of climatic conditions and geographic features of Slovakia, on the basis of the examination of the approaches of domestic and foreign authors, a set of appropriate preconditions for the mountain destinations in Slovakia is defined:

- altitude limit 700 MASL (Kuklica et al., 1965);

- transport accessibility of destination (Gúčik, 2011); 
- primary supply (forest and meadows) in such a quantity and quality, which is attractive for the visitors (Kopšo, 1992; Patúš, 2004; Gúčik \& Pěč, 2011);

- adequate infrastructural facilities, which allow a stay in the destination and provision of services to visitors (Patúš, 2004; Gúčik, 2011; Gajdošík, 2014);

- possibilities to participate in the leisure activities, typical of a mountain destination (Medlik, 2003; Patúš, 2004; Keller, 2012);

- an active destination management organization or a core business entity (Kämpf \& Weber, 2005; Flagestad \& Hope, 2012; Šebová, 2014).

It is impossible to manage something that cannot be measured. It is therefore important to measure the innovation implemented in tourism destinations. Nowadays, the measurement of innovations is receiving increased attention. However, the principles of measuring the innovation are different (Table 1) and their quantitative expression seems to be necessary basis for further research.

In the context of measuring the innovations, two fundamental approaches are distinguished. The first one lies in the measuring of the effectiveness of the innovation (detecting the benefits of innovation) and the second one represents the innovation rate (quantifying the destination focus on innovations). The measurement of the effectiveness of innovation is appropriate for the internal decisions in tourism destinations, for detecting whether it is profitable to implement the innovation, examining what the real benefits of innovation are and the extent to which the implemented innovation is successful on the market. The determination of the innovation rate is associated with the external environment of the tourism destinations because this indicator is primarily used for the comparison of these destinations and ranking their innovation performance.

Table 1 Principle of measuring the innovation

\begin{tabular}{|l|l|l|l|}
\hline $\begin{array}{l}\text { Approaches } \\
\text { to measuring }\end{array}$ & $\begin{array}{l}\text { Process } \\
\text { of measurement }\end{array}$ & $\begin{array}{l}\text { Aim } \\
\text { of measurement }\end{array}$ & $\begin{array}{l}\text { Method } \\
\text { of measurement }\end{array}$ \\
\hline $\begin{array}{l}\text { Measuring the effec- } \\
\text { tiveness of innovation } \\
\text { tation of innovation }\end{array}$ & $\begin{array}{l}\text { Discover if it is effective } \\
\text { to implement the inno- } \\
\text { vation }\end{array}$ & $\begin{array}{l}\text { e. g. expected innova- } \\
\text { tion benefit cost ratio }\end{array}$ \\
\cline { 2 - 4 } & $\begin{array}{l}\text { After the implementati- } \\
\text { on of innovation }\end{array}$ & $\begin{array}{l}\text { Discover what the ef- } \\
\text { fects of innovation are }\end{array}$ & $\begin{array}{l}\text { e. g. real innovation } \\
\text { benefit cost ratio }\end{array}$ \\
\hline $\begin{array}{l}\text { Determining the inno- } \\
\text { vation rate }\end{array}$ & $\begin{array}{l}\text { Quantify the focus } \\
\text { of innovation }\end{array}$ & $\begin{array}{l}\text { Determining to what } \\
\text { extent business is } \\
\text { connected with the } \\
\text { implementation of in- } \\
\text { novation }\end{array}$ & $\begin{array}{l}\text { e. g. the ratio of the } \\
\text { innovation costs to the } \\
\text { total costs or the score } \\
\text { of the implemented } \\
\text { innovation }\end{array}$ \\
\hline
\end{tabular}

Source: Author's research (2015) 
Only a few authors (Weiermair, 2006; Volo, 2005; Pikkemaat \& Walder, 2006) pay attention to the measuring of innovations in the tourism destinations. These are a few initial empirical studies of appropriate methods, models and tools for measuring innovation.

These authors agree that the innovative subject can be not only a business, but also the whole industry, sector, destination, region or state. The criteria taken into account when measuring innovations are the technical parameters (e.g. educational achievement), market and economy parameters (e.g. maximizing the turnover or minimizing the costs) and social parameters (e.g. influence on environment or society).

The authors identify a problem if they try to measure the effect of the innovation implemented in the tourism destination. The tourism supply is created as a chain of products and services. To determine the destination innovation rate, it is necessary to analyse the innovations implemented in individual businesses, which are part of the tourism chain, followed by the synthesis of findings in one particular indicator (innovation rate). In 2006 Pikkemaat and Walder realized a pilot project aimed at measuring the innovations in the destinations in the Austrian Alps. The findings create a model which enables to identify the innovative activity and the innovation rate in the individual tourism businesses, destinations, but also in different industries.

In the tourism theory and practice, there have been some efforts to measure the effectiveness of innovations and determination of the innovation rate of the businesses and destinations. Such findings create more opportunities for decisions on the implementation of innovations, evaluation of their effects, intercomparison and for determining the influence of the implemented innovations on the competitiveness or regional development.

\section{Methodology}

The topic of the paper, as well as personal experience, lead to the conclusion that the examinationof the innovations only in the mountain destinations in Slovakia would be insufficient. In the world there are countries with mountain resorts of international importance where the innovations are determined by market trends. According to the International Report on Snow and Mountain Tourism (Vanat, 2014), among the most competitive mountain destinations (Canada, France, Switzerland, Austria, Italy) Switzerland was the best. Switzerland has a similar primary tourism supply as Slovakia. In the Swiss Alps tourism has had a tradition for 150 years. The offer of the mountain destinations varies, both in winter and in summer season. It is known that the Swiss mountain destinations are situated in different phase of the destination life cycle as the Slovak ones. But they have already gone through the phases that the Slovak mountain destinations will have to pass. These assumptions can help the Slovak mountain destinations to anticipate and avoid the mistakes that were made in Switzerland. The Swiss mountain destinations may also be a good practice for upgrading the Slovak mountain destinations. 
The aim of this paper is to explore the structure of the innovation in the Slovak and Swiss mountain destinations and to discover their innovation rate.

To meet the aim of the article, the innovations made by the destination management organizations and by the ski lift operators are analysed as these two stakeholders play the most important role in the mountain destination innovation.

There are 107 mountain destinations in Slovakia and 39 mountain destinations in Switzerland (Lencsésová, 2014). In the article the data from 34 Slovak and 29 Swiss mountain destinations are used. The research in the Slovak destinations was made on the basis of the investigation of annual reports in those mountain destinations, which publish the annual reports. In other destinations it had to be used on the basis of the questionnaire survey. The managers of the destinations were asked about the implemented innovations in 2013. The research in the Swiss destinations is based on the analysis of 29 annual reports, where the innovations implemented in 2013 are analysed and compared. To increase the credibility of the research, the Slovak and some of the Swiss (Davos-Klosters, St. Moritz, Zermatt) mountain destinations were visited to discover the current state of the innovation in the destinations.

Based on the analysis of theory and current state of the Slovak and Swiss mountain destinations, it is supposed that the Slovak mountain destinations should innovate in the sense of increasing their competitiveness and creating an attractive offer for the summer season because they are situated in a lower altitude and their economy is influenced by the lack of snow (Lencsésová, 2014). That is the reason of the assumption that in the Slovak mountain destinations the technological innovations are predominant. On the contrary, the Swiss mountain destinations are considered highly competitive with the best ski lift capacities, which enables the authors of this study to suppose that the innovations should no longer focus on the increase of capacity, but on the sustainable development by non-technological innovations.

In the hypothesis, it is supposed that the Slovak mountain destinations have a higher innovation rate in the area of the technological innovations and the Swiss destinations have a higher innovation rate in the area of the non-technological innovations. The hypothesis is tested by determining the innovation rate. The innovations, which were identified by the survey and the analysis of the annual reports, are divided into two groups:

- technological innovations, which are further divided into the quantitative and qualitative innovations;

- non-technologicalinnovations, whicharedividedinto product, price, communicationand distribution innovations.

The diversification of the innovation is based on the terminology of the Oslo Manual (OECD, 2005), which also distinguishes the technological and non-technological innovations. The chosen classification allows to determine the influence of the innovations on the mountain destination development (Figure 1). The technological quantitative innovations have only a little impact on the destination sustainable development $\left(\mathrm{x}_{1}\right)$ but several times higher impact on the increaseof the capacity of the mountain destination 
$\left(\mathrm{y}_{1}\right)$. On the contrary, the non-technological innovations influence more the sustainable development $\left(\mathrm{x}_{2}\right)$ of the destination than the increase of the capacities $\left(\mathrm{y}_{2}\right)$.

Figure 1 Innovation influence on the mountain destination development

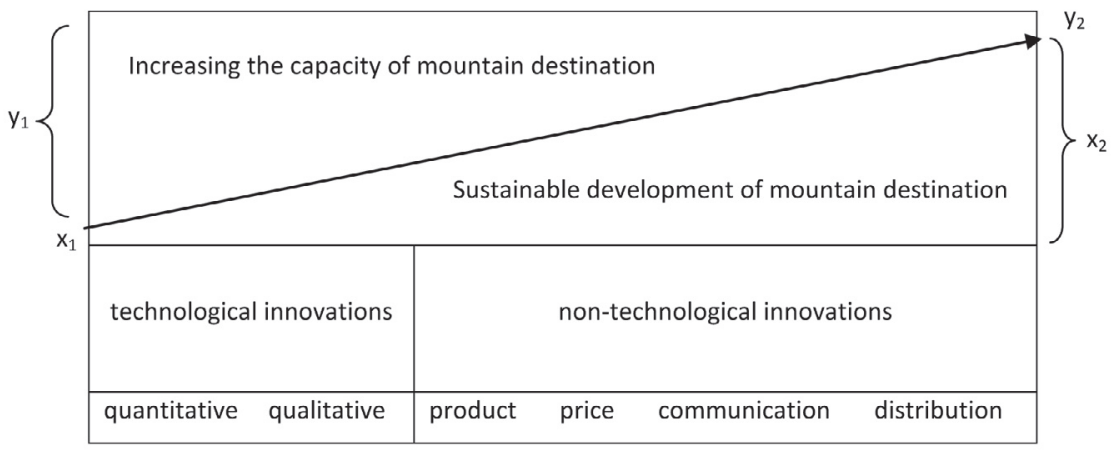

Source: Author's research (2015)

Innovations that were implemented by the destination management organization and ski lift operators in 2013 are examined. Every innovation was assigned with the points from the interval $\langle 0 ; 3\rangle$. Assigning the points is based on the methodology of Pikkemaat and Walder (2006), which was adapted according to the conditions of this survey in the mountain destinations. Examples of assigning the points to the innovations are presented in Table 2.

The innovation rate in one innovation group (e.g. technological quantitative innovation) is the ratio of the sum of the assigned points and the number of the calculated innovations. On the basis of the synthesis of the innovation rates into a single unit, a comprehensive indicator for the whole mountain destination is obtained (1).

$$
M_{I}=\frac{\Sigma_{I_{t c h}}+\sum_{I_{n t c h}}}{n_{I}} M_{I}=\frac{\sum_{I_{t c h}}+\sum_{I_{n t c h}}}{n_{I}}
$$

where: $\quad \mathrm{M}_{\mathrm{I}}$ is the comprehensive innovation rate of the mountain destination, $\mathrm{I}_{\text {tch }}$ - sum of the obtained points of technological innovation,

$\mathrm{I}_{\text {ntch }}$ - sum of the obtained points of non-technological innovation,

$\mathrm{n}_{\mathrm{I}}-$ number of innovation groups.

As not all the Slovak and Swiss destinations were examined, a statistical generalization has to be made. To formulate generally applicable conclusions, the innovation rate should be generalized for all the Slovak and Swiss mountain destinations. The generalization of the innovation rate is done on the basis of testing the confidence interval of the mean based on a simple random sample from a normal distribution. It is necessary to determine whether the sample has a normal distribution. For this testing the statistic normality tests - Kolmogorov - Smirnov and Shapiro-Wilk W tests are used. If the significance is higher than $\boldsymbol{\alpha}=0.05$, the assumption for the normality of the data is accepted 
and can perform the parametric test. The result of the innovation rate generalization consists in the finding of the average value, lower and upper limit, median, standard deviation and variation coefficient of the innovation rate for all the Slovak and Swiss mountain destinations.

Table 2 Ranking of the innovations in the innovation groups

\begin{tabular}{|c|c|c|c|c|c|}
\hline \multirow{2}{*}{$\begin{array}{l}\text { Characteristics } \\
\text { of innovation }\end{array}$} & \multirow{2}{*}{$\begin{array}{l}\text { Innovation } \\
\text { group }\end{array}$} & \multicolumn{4}{|c|}{ Ranking of the innovation } \\
\hline & & 0 & 1 & 2 & 3 \\
\hline \multirow{2}{*}{ 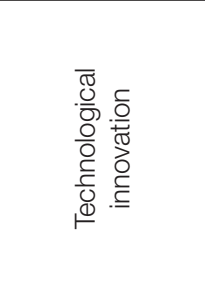 } & $\begin{array}{l}\text { Quantitative } \\
\text { innovation }\end{array}$ & $\begin{array}{l}\text { No implemented } \\
\text { innovation }\end{array}$ & $\begin{array}{l}\text { Building new or } \\
\text { enlarging the exist- } \\
\text { ing parking area }\end{array}$ & $\begin{array}{l}\text { Replacement of } \\
\text { the old ski lift with } \\
\text { a new one with } \\
\text { higher capacity }\end{array}$ & $\begin{array}{l}\text { Building a new } \\
\text { ski lift }\end{array}$ \\
\hline & $\begin{array}{l}\text { Qualitative } \\
\text { innovations }\end{array}$ & $\begin{array}{l}\text { No implemented } \\
\text { innovation }\end{array}$ & $\begin{array}{l}\text { Replacement of } \\
\text { the old ski lift with } \\
\text { a new one with the } \\
\text { same capacity }\end{array}$ & $\begin{array}{l}\text { Extending the area } \\
\text { of artificial snow }\end{array}$ & $\begin{array}{l}\text { Building a new } \\
\text { sun terrace }\end{array}$ \\
\hline \multirow{4}{*}{ 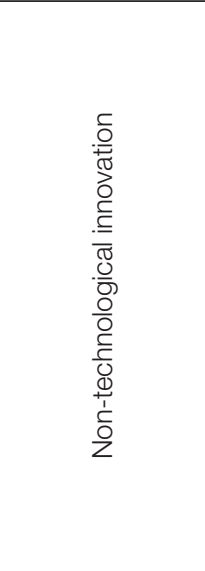 } & $\begin{array}{l}\text { Product } \\
\text { innovation }\end{array}$ & $\begin{array}{l}\text { No implemented } \\
\text { innovation }\end{array}$ & $\begin{array}{l}\text { Creating a desti- } \\
\text { nation card }\end{array}$ & $\begin{array}{l}\text { Creating thematic } \\
\text { tourist routes }\end{array}$ & $\begin{array}{l}\text { Public transport } \\
\text { included in the } \\
\text { holiday package }\end{array}$ \\
\hline & $\begin{array}{l}\text { Price in- } \\
\text { novation }\end{array}$ & $\begin{array}{l}\text { No implemented } \\
\text { innovation }\end{array}$ & $\begin{array}{l}\text { Offer of price re- } \\
\text { duction to support } \\
\text { visitors' demand }\end{array}$ & $\begin{array}{l}\text { Creating of holiday } \\
\text { packages with } \\
\text { more valuable } \\
\text { prices }\end{array}$ & $\begin{array}{l}\text { Dynamic creation } \\
\text { of prices for ticket } \\
\text { and passes sold } \\
\text { via the Internet }\end{array}$ \\
\hline & $\begin{array}{l}\text { Innovation } \\
\text { in commu- } \\
\text { nication }\end{array}$ & $\begin{array}{l}\text { No implemented } \\
\text { innovation }\end{array}$ & $\begin{array}{l}\text { Customizing the } \\
\text { web page to } \\
\text { mobile devices }\end{array}$ & $\begin{array}{l}\text { Creating of mobile } \\
\text { device application }\end{array}$ & $\begin{array}{l}\text { New destina- } \\
\text { tion's web page }\end{array}$ \\
\hline & $\begin{array}{l}\text { Innovation } \\
\text { in distribu- } \\
\text { tion }\end{array}$ & $\begin{array}{l}\text { No implemented } \\
\text { innovation }\end{array}$ & $\begin{array}{l}\text { Selling ticket and } \\
\text { passes via internet }\end{array}$ & $\begin{array}{l}\text { Creating of the } \\
\text { internet platform } \\
\text { to sell the accom- } \\
\text { modation in apart- } \\
\text { ment houses }\end{array}$ & $\begin{array}{l}\text { Using of a com- } \\
\text { plex information } \\
\text { and reservation } \\
\text { system in the } \\
\text { destination }\end{array}$ \\
\hline
\end{tabular}

Source: Pikkemaat and Walder (2006), and author's research (2015)

\section{Results}

Based on the examination of the implemented innovations in the Slovak and Swiss mountain destinations, the majority of these destinations introduced new artificial snowmaking systems and they extended the area covered with artificial snow. In Switzerland, there is less attention paid to the increase in the transport capacity of ski lifts. The innovations in Switzerland are focused on additional services and creation of various alternative offers for leisure in the summer time, which is not seen in many Slovak destinations. The installation of technologies that allow to obtain energy from renewable sources in the Swiss mountain resort is also remarkable. 
In both countries the structure of the non-technological innovations correspond to market trends. They deal with the creation of a complex package of services on the one hand, and the development of information technology on the other hand. In the Swiss destinations the focus on the public transport, products for children and beginners, new kinds of marketing (cross-marketing, affiliate marketing, key media management), pricing with yield management techniques and internet sales of apartment houses is dominated

The Slovak mountain destinations reached the highest innovation rate in the group of the technological qualitative innovations (Table 3). The reason is that $97 \%$ of the analysed Slovak mountain destinations introduced in 2013 new artificial snowmaking systems or extended the area covered with artificial snow. Other very frequent innovations included the building of the new ski lifts, replacement of the old ski lifts with new one with a higher transport capacity or enlargement of the parking area.

Table 3 Average innovation rate in various innovation groups

\begin{tabular}{|c|c|c|c|c|c|c|}
\hline \multirow{3}{*}{ Country } & \multicolumn{6}{|c|}{ Average obtained values } \\
\hline & \multicolumn{2}{|c|}{ Technological innovation } & \multicolumn{4}{|c|}{ Non-technological innovation } \\
\hline & $\begin{array}{l}\text { Quantitative } \\
\text { innovation }\end{array}$ & $\begin{array}{l}\text { Qualitative } \\
\text { innovation }\end{array}$ & Product & Price & Communication & Distribution \\
\hline \multirow[t]{3}{*}{ Slovakia } & 2.04 & 2.14 & 1.54 & 0.11 & 1.89 & 0.36 \\
\hline & \multicolumn{2}{|c|}{2.09} & \multicolumn{4}{|c|}{0.97} \\
\hline & \multicolumn{6}{|c|}{1.53} \\
\hline \multirow[t]{3}{*}{ Switzerland } & 0.86 & 1.79 & 2.07 & 0.11 & 1.64 & 0.64 \\
\hline & \multicolumn{2}{|c|}{1.33} & \multicolumn{4}{|c|}{1.12} \\
\hline & \multicolumn{6}{|c|}{1.22} \\
\hline
\end{tabular}

Source: Author's research (2015)

The lower innovation rates were achieved in the group of the non-technological innovations in the case of the Slovak mountain destinations. The highest attention is paid to the innovations in communication (1.89), this is thanks to the creation of a new web page or an account on the social networks. The management of the Slovak mountain destinations implements more technological than the non-technological innovations.

The qualitative technological innovations of the Swiss mountain destinations achieved twice higher innovation rate than the quantitative innovation. The management of the Swiss mountain destinations pays higher attention to the improvement of the quality, repair and maintenance of the existing capacities than building the new ones. In the group of the non-technological innovations, the product innovations have the higher innovation rate. The reason is the creation of the packages with public transport and a new alternative offer for the summer season. The innovations in communication and distribution are aimed at new trends in information technologies. 
Table 4 Test of normality of the innovation rate in the Slovak mountain destinations

\begin{tabular}{|l|c|c|c|c|c|c|}
\hline \multirow{2}{*}{$\begin{array}{l}\text { Innovation rate in } \\
\text { mountain destina- } \\
\text { tions }\end{array}$} & \multicolumn{3}{|c|}{ Kolmogorov-Smirnov } & \multicolumn{3}{c|}{ Shapiro-Wilk } \\
\cline { 2 - 7 } & Statistics & $\begin{array}{c}\text { Number } \\
\text { of destinations }\end{array}$ & Sig. & Statistics & $\begin{array}{c}\text { Number } \\
\text { of destinations }\end{array}$ & Sig. \\
\hline Slovakia & 0.099 & 34 & 0.200 & 0.972 & 34 & 0.633 \\
Switzerland & 0.107 & 29 & 0.200 & 0.940 & 29 & 0.111 \\
\hline
\end{tabular}

Source: Author's research (2015)

To formulate generally applicable conclusions, the comprehensive average innovation rate (Table 4) of the Slovak (1.53) and Swiss (1.22) mountain destinations is generalized. According to the observed significance, which is in the both used tests higher than $\boldsymbol{\alpha}(0.05)$, the assumption for the normality of the data is accepted. Thus, the confidence interval of the mean, based on a simple random sample from a normal distribution, can be tested.

Table 5 Descriptive statistics and confidence interval of the innovation rate of the mountain destinations.

\begin{tabular}{|l|c|c|}
\hline \multirow{2}{*}{ Statistics } & \multicolumn{2}{|c|}{ Obtained value } \\
\cline { 2 - 3 } & Slovakia & Switzerland \\
\hline Average & 1.30 & 1.17 \\
The lower limit & 1.05 & 0.92 \\
The upper limit & 1.54 & 1.41 \\
Median & 1.33 & 1.17 \\
Standard deviation & 0.65 & 0.64 \\
Coefficient of variation & 0.42 & 0.41 \\
Min & 0.00 & 0.00 \\
Max & 3.00 & 3.00 \\
\hline
\end{tabular}

Source: Author's research (2015)

It is concluded, with $95 \%$ confident rate, that the mean of the Slovak mountain destinations innovation rate is 1.30 and 1.17 of Swiss mountain destinations. The interval of the innovation rate in all the Slovak mountain destinations ranges between 1.05 and 1.54 and in the Swiss destinations between 0.92 and 1.41. The maximum of the innovation rate, which they could achieve, is 3 and the minimum is 0 . 


\section{Discussion}

It is difficult to quantify the innovations in a tourism destination because of a high number of stakeholders involved in their implementation. For this reason there are only a few authors, who made some initial empirical studies about the models suitable for measuring the innovations in the tourism destinations. Based on the survey made by Pikkemaat and Walder (2006), the innovation rate in 34 Slovak and 29 Swiss mountain destinations was measured. The results with the survey made in 2006 in the Austrian mountain destinations (Table 6) are now compared below.

Table 6 Comparison of the innovation rate in the mountain destinations

\begin{tabular}{|l|c|c|c|}
\hline Indicator & Slovakia & Switzerland & Austria \\
\hline $\begin{array}{l}\text { Number of the examined } \\
\text { mountain destinations }\end{array}$ & 34 & 29 & 7 \\
\hline Average innovation rate & 1.30 & 1.17 & 0.98 \\
\hline The lower limit & 1.05 & 0.92 & 0.61 \\
\hline The upper limit & 1.54 & 1.41 & 1.83 \\
\hline
\end{tabular}

Source: Pikkemaat and Walder (2006), and author's research (2015)

In the monitored countries, the identified innovation rates differ. The highest are in Slovakia, lower in Switzerland and the lowest in Austria. This may be related to the various life cycle phase of the destinations. Due to the low number of analysed mountain destinations in Austria, it is impossible to formulate any other conclusions.

The innovations should correspond to the destination life cycle phase and the state of the development of mountain destination. The influence of the innovations on the mountain destination development was explained in the part on methodology. For further research it is recommended to answer the question to what extent the innovations influence the sustainable development of mountain destinations and the possibilities how the innovations can improve the current state of the sustainable development of tourism mountain destination. As it has been mentioned above, in the Swiss destinations, new environmental friendly technologies or created packages with public transport have been implemented.

\section{Conclusion}

Over the years, the innovations have become an instrument for increasing the competitiveness. Not only the tourism business, but also the destinations have to implement the innovations to ensure their competitive advantage and meeting the needs of their visitors. It is evident that the position of the destination on the tourism market can be improved by introducing the innovations. The author's attempt was to investigate the 
innovation implemented in the Slovak and Swiss mountain destinations and to provide their measurement.

It is evident that only a quantitative comparison of the innovation rate of the Slovak and Swiss mountain destinations would be insufficient. Characteristic features, capabilities and performance indicators on the one hand, and the tendencies in the number of visitors on the other hand, have indicated that these mountain destinations differ not only in terms of geomorphology and tourism offer, but also in terms of life cycle phases. The number of visitors in the Swiss mountain destinations has been decreased since 1993 (Vanat, 2014), which indicates that the mountain destinations are in the phase of decline. The innovation is now an appropriate tool for the recovery, re-consolidation and stagnation. On the contrary, the number of visitors and capacities in the Slovak mountain destinations has grown steadily (Vanat, 2014). For this reason, it can be concluded that they are still in the phase of consolidation and they are gradually getting to the stage of stagnation. This is supported by the historical development of tourism in the mountain destinations, which the Swiss developed in the mid of the $19^{\text {th }}$ century and the Slovaks in the early of the $20^{\text {th }}$ century. It is also influenced by different economic regimes in the $20^{\text {th }}$ century and by tourism development in Slovakia after the Velvet revolution.

Based on the proposed methodology, it can be concluded that the Slovak mountain destinations achieve a higher innovation rate in the group of the technological innovations and the Swiss destinations in the group of the non-technological innovation. The assumption that the Slovak mountain destinations should upgrade their technical infrastructure in order to be competitive and to create an attractive offer in the summer period, of course, in accordance with the principles of the sustainable development, has been also confirmed. The fact that the Swiss mountain destinations have a sufficient supply of the ski lifts and that they have to innovate mainly their products, price, communication and distribution has been confirmed, too.

The aim of the paper, to explore the structure of the innovation in the Slovak and Swiss mountain destinations and to find out their innovation rate, was fulfilled. First, it is defined from the theoretical point of view. Second, the studies measuring the innovation in tourism destinations were analysed. The structure of the innovations and the innovation rate in 34 Slovak and 29 Swiss mountain destinations was made. The analysed innovations were divided into the innovation groups and ranked according to the proposed methodology in order to determine the innovation rate. The innovations are an appropriate instrument for tourism development in a mountain destination according to the principles of sustainable development.

A limitation factor may be the absence of annual reports in some Slovak mountain destinations because the results could be after the investigation of the unavailable annual reports slightly different. Thus, based on the deficiencies and limitations met during this research, it is recommended to draw attention to the relationship between the innovation rate and the destination life cycle in future research studies. 


\section{References}

Bourdeau, P. (2009). Mountain tourism in a climate of change. In R. Jandl, et al. (Eds.), Global Change and Sustainable Development in Mountain Regions (pp. 99-136). Innsbruck: Innsbruck University Press.

Flagestad, A., \& Hope, C. A. (2001). Strategic success in winter sports destinations: a sustainable value creation perspective. Tourism management, 22(5), 445-461.

Flagestat, A., \& Hope, C. A. (2012). Identification and Prioritisation of Stakeholders in a Winter Sports Destination for Measuring Organisational Performance. A Norwegian Perspective. In EURAC Research, Changing paradigms in sustainable mountain tourism research: EURAC International Conference, Brixen/Bressanone, October 25-27, 2012. Bolzano: The European Academy of Bozen.

Gajdošík, T. (2014). Plánovanie výstavby v ciel'ovom mieste cestovného ruchu v kontexte udržatelného rozvoja (Construction planning in tourism destination in the context of sustainable development). In R. Šperková \& P. Kůdelová (Eds.), Nové trendy v gastronomii, hotelnictví a cestovním ruchu: sbornik přispěvků ze sedmé mezinárodni conference: 24. Dubna 2014 (New trends in gastronomy, hotel industry and tourism: proceedings of $7^{\text {th }}$ annual international conference: $24^{\text {th }}$ April 2014) (pp. 31-41). Brno: Vysoká škola obchodní a hotelová.

Gúčik, M. (2011). Cestovný ruch. Politika a ekonómia (Tourism. Politics and Economy). Banská Bystrica: Slovak-Swiss Tourism.

Gúčik, M., \& Pěč, J. (2011). Klasifikácia stredísk cestovného ruchu na Slovensku (Classification of Slovak Tourism Destinations). Ekonomická revue cestovného ruchu (Economic Review of Tourism), 44(1), 47-53.

Horák, V., Jurčacko, D., \& Izáková E. (1985). Typológia stredísk cestovného ruchu a rekreácie (Typology of tourism and recreational destinations). Bratislava: ERPO.

Kämpf, R., \& Weber, K. (2005). Erfolgsfaktoren im alpinen Tourismus. Bern: Staatssekretariat für Wirtschaft (Seco).

Keller, P. F. (2012). Changing Paradigm in Sustainable Mountain Tourism: A critical analysis from a global perspective. In EURAC Research, Changing paradigms in sustainable mountain tourism research: EURAC International Conference, Brixen/Bressanone, October 25-27, 2012. Bolzano: The European Academy of Bozen.

Kopšo, E. et al. (1989). Materiálno-technická základňa cestovného ruchu a spoločného stravovania (Tourism and hospitality infrastructure). Bratislava: Slovenské pedagogické nakladatelstvo.

Kopšo, E. et al. (1992). Geografia cestovného ruchu (Tourism geography). Bratislava: Slovenské pedagogické nakladatel'stvo.

Kuklica, J. et al. (1965). Metodické pokyny pre výstavbu komplexných stredísk cestovného ruchu a rekreácie (Guidlines for the construction of complex tourism and recreational destinations). Praha: Vydavatelství obchodu.

Kuščer, K. (2013). Determining Factors of Mountain Destination Innovativeness. Journal of Vacation Marketing, 19(1), 41-54. DOI: 10.1177/1356766712461404 
Lencsésová, Z. (2014). Osobitosti skúmania horských stredísk na Slovensku (Research specificities of mountain destinations in Slovakia). In P. Hronček, L. Smerek, \& K. Dubcová (Eds.), Scientia Iuventa 2014 elektronický zdroj zbornik príspevkov z medzinárodnej doktorandskej konferencie (Scientia Iuventa 2014: proceedings from international scientific conference of PhD. Student) (pp. 239-249). Banská Bystrica: Belianum.

Mariot, P. (1983). Geografia cestovného ruchu (Tourism Geography). Bratislava: Veda.

Mariot, P. (2001). Príspevok k typizácii stredísk cestovného ruchu (Contribution to the typology of tourism destinations). Geografický časopis, 53(4), 307-319.

Matto, T. D., \& Scott, D. (2008). Sustainable Ski Resort Principles. In S. Gössling et al., Sustainable Tourism Futures. Perspectives on Systems, Restructuring and Innovations (pp. 131-151). New York: Routledge.

Medlik, S. (2003). Dictionary of travel, tourism and hospitality. Oxford: Elsevier Science.

Nepal, S., \& Chipeniu, R. (2005). Mountain Tourism: Toward a Conceptual Framework. Tourism Geographies, 7(3), 313-333.

OECD/Eurostat. (2005). Oslo Manual: Guidelines for Collecting and Interpreting Innovation Data, 3rd Edition. Paris: OECD Publishing. DOI: 10.1787/9789264013100-en

Patúš, P. (2004). Problémy manažmentu strediska cestovného ruchu (Problems of destination management). Banská Bystrica: Matej Bel University.

Pikkemaat, B. \& Walder, B. (2006). Innovationsmessung in touristischen Destinationen: Modellierung und Anwendung. In R. Bachleitner et al. (Eds.), Innovationen in der Tourismusforschung: Methoden und Anwendungen (pp. 113-139). Berlin: LIT Verlag.

Šebová, L. (2014). Inštitucionálne a právne aspekty fungovania organizácií cestovného ruchu (Institutional and legal aspect of tourism organizations functioning). In M. Gúčik (Ed.), Folia Turistica 4, zbornik vedeckých prác (Folia Turistica 4, Proceedings of scientific papers) (pp. 500-509). Banská Bystrica: Matej Bel University, Faculty of Economics.

Vanat, L. (2014). 2014 International Report on Snow E Mountain Tourism: Overview of the key industry figures for ski resorts. Retrieved from http://www.isiaski.org/download /20140517_ISIA_Vuokatti_1b_presentation_vanat.pdf

Volo, S. (2005). Tourism Destination Innovativeness. In P. Keller \& T. Bieger (Eds.), Innovation in Tourism - Creating Customer Value: $55^{\text {th }}$ Congress 2005, Brainerd, USA (pp. 199-211). St. Gallen: AIEST.

Weiermair, K. (2006). Product improvement or innovation: what is the key to success in tourism? In OECD, Innovation and Growth in Tourism (pp. 53-69). Paris: OECD Publishing. DOI: 10.1787/9789264025028-5-en 